\title{
A cytosolic trehalase from the thermophilic fungus Humicola grisea var. thermoidea
}

\author{
Leonardo Cardello, Héctor Francisco Terenzi and João Atilio Jorge
}

Author for correspondence: João A. Jorge. Tel: +55 16633 3255. Fax: + 55166335015.

Departamento de Biologia, Faculdade de Filosofia,

Ciências e Letras de Ribeirão Preto, Universidade de São

Paulo, 14040-901 Ribeirão

Preto, São Paulo, Brazil

\begin{abstract}
A cytosolic trehalase was purified from the thermophilic fungus Humicola grisea var. thermoidea. The apparent molecular mass of the purified native enzyme was estimated to be $360 \mathrm{kDa}$ by gel filtration chromatography. A single polypeptide band of approximate molecular mass $120 \mathrm{kDa}$ was detected by SDS-PAGE, suggesting that the native enzyme was composed of three identical polypeptides. The carbohydrate content of the enzyme was estimated to be $12 \%$. The pl of the enzyme, estimated by electrofocusing, was about $4 \cdot 0$. The purified trehalase was specific for trehalose and its activity was stimulated by manganese, calcium and cobalt and inhibited by aluminium chloride, copper sulfate, ADP and ATP. Sugars such as cellobiose, lactose, sucrose, fructose and maltose also showed some inhibitory effect which was abolished in the presence of calcium. The purified cytosolic trehalase exhibited an apparent $K_{\mathrm{m}}$ of $0.86 \mathrm{mM}$, a pH optimum of 5.5 and an optimum temperature of $60^{\circ} \mathrm{C}$. Treatment with calcium induced disaggregation of the enzyme into three components. Apparently, calcium-induced disaggregation was not a prerequisite for calcium-mediated activation of the enzyme. The disaggregated trehalase was more labile to temperature than the native enzyme. The properties of the two $H$. grisea trehalases: the cytosolic enzyme and the conidial one, were compared.
\end{abstract}

Keywords: Humicola grisea var. thermoidea, cytosolic trehalase, conidial trehalase

\section{INTRODUCTION}

Trehalose ( $\alpha$-D-glucopyranosyl- $\alpha$-D-glucopyranoside) is a non-reducing disaccharide which is found in a large variety of organisms including bacteria, yeasts, filamentous fungi, plants and insects (Elbein, 1974). Trehalose serves as an endogenous carbon reserve for a number of physiological functions (Panek, 1963; Panek \& Souza, 1964; Hey-Ferguson et al., 1973; Hirokasu \& Shimoda, 1981; Thevelein, 1984) or as a protectant against several forms of environmental stress (Van Laere, 1989).

Trehalose is hydrolysed to glucose by the enzyme trehalase ( $\alpha, \alpha$-trehalose glucohydrolase, EC 3.2.1.28). The biochemical properties of this enzyme, which has been isolated from different sources, are highly variable (Elbein, 1974). Fungal trehalases can be grouped into two distinct categories: the so-called non-regulatory trehalases which have an acid $\mathrm{pH}$ optimum and high heat stability, and the so-called regulatory trehalases which have a neutral $\mathrm{pH}$ optimum and low thermal stability (Thevelein, 1984). Some fungi such as Saccharomyces cerevisiae (Mittenbühler \& Holzer, 1988; App \& Holzer, 1989) and Schizo- saccharomyces pombe (De Virgilio et al., 1991) possess both types of trehalase.

Amon thermophilic fungi the genus Humicola is reported to be a good source of trehalase (Prasad \& Maheswari, 1978; Zimmerman et al., 1990). An extracellular trehalase activity associated with $H$. grisea var. thermoidea conidia was characterized in a previous study from our laboratory (Zimmerman et al., 1990). We considered it worthwhile to investigate the possibility that another trehalase exists in $H$. grisea, in addition to the enzyme which accumulates on the surface of conidia.

Here we report the purification and partial biochemical characterization of a cytosolic trehalase from $H$. grisea var. thermoidea. The properties of this cytosolic trehalase were compared with those of the conidial enzyme, in order to improve our knowledge about the trehalase system of this filamentous fungus.

\section{METHODS}

Organism and growth conditions. The Humicola strain was isolated from Brazilian soil and classified as $H$. grisea var. thermoidea (Peralta et al., 1990). The fungus was maintained in 


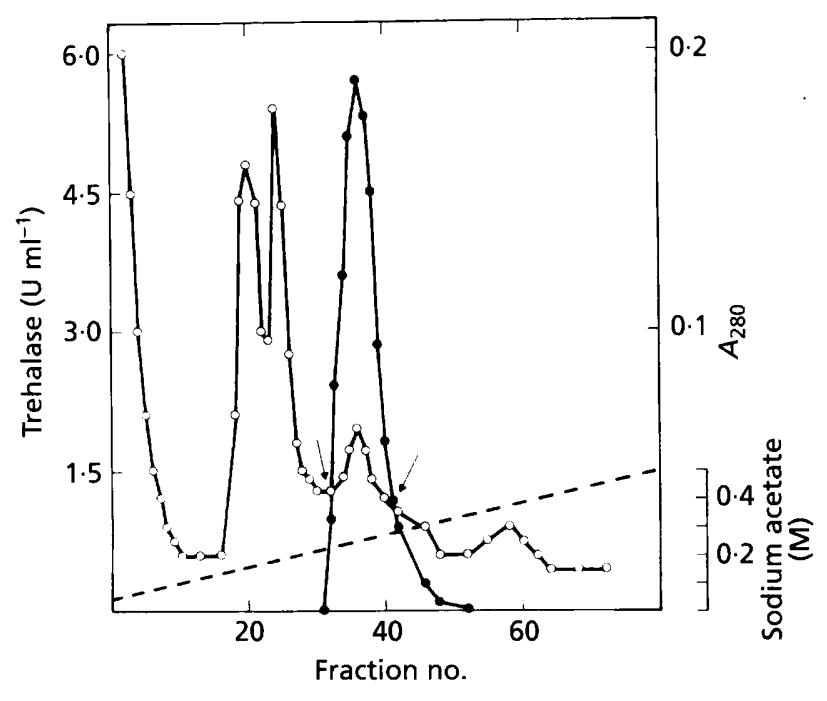

Fig. 1. DEAE-Trisacryl chromatography of cytosolic trehalase. The enzyme activity recovered from the Fractogel column was applied to a DEAE-Trisacryl column $(15.0 \times 1.0 \mathrm{~cm})$ equilibrated with $50 \mathrm{mM}$ sodium acetate buffer $\mathrm{pH} 5.5$, and eluted with a gradient of the same buffer $(50-500 \mathrm{mM})(--)$ at a flow rate of $20 \mathrm{ml} \mathrm{h}^{-1}$. The arrows indicate the pooled fractions. Trehalase activity; $O, A_{280}$.

the laboratory on slants of solid oatmeal baby food (Peralta $t$ t al., 1990). Conidia from 10-d-old cultures were inoculated into liquid medium of the following composition: $0.2 \%$ sodium nitrate, $0.1 \%$ potassium phosphate monobasic, $0.05 \%$ magnesium sulfate, $0.8 \%$ yeast extract (Difco), $0 \cdot 1 \%$ potassium chloride, $1.0 \%$ mannitol. One millilitre of trace elements solution $\left(0 \cdot 1 \% \mathrm{FeSO}_{4} .7 \mathrm{H}_{2} \mathrm{O}\right.$ and $\left.0.30 \% \mathrm{ZnSO}_{4}\right)$ was added to $100 \mathrm{ml}$ of culture medium and the $\mathrm{pH}$ was adjusted to 6.0 with diluted $\mathrm{NaOH}$. The cultures were incubated at $45^{\circ} \mathrm{C}$ with agitation (140 oscillations $\mathrm{min}^{-1}$ ).

Extraction and purification of cytosolic trehalase. The mycelia grown as described above were harvested by filtration, rinsed with distilled water, blotted on filter paper and stored at $-15^{\circ} \mathrm{C}$ until use. The mycelial mass ( $100 \mathrm{~g})$ was ground in a mortar with acid-washed sand at $0^{\circ} \mathrm{C}$. Cell disruption was continued for an additional $30 \mathrm{~min}$ after addition of $10 \mathrm{ml}$ cold $100 \mathrm{mM}$ sodium acetate buffer, pH $5 \cdot 5$ (acetate buffer) (g mycelium) ${ }^{-1}$. The slurry was centrifuged at $10000 \mathrm{~g}$ for $20 \mathrm{~min}$ and the supernatant (crude extract) was saved. Solid ammonium sulfate was added to the crude extract to achieve $75 \%$ saturation and the mixture was stirred for $30 \mathrm{~min}$. The suspension was stored overnight in a cold room. Precipitated protein was collected by centrifugation at $25000 \mathrm{~g}$ for $30 \mathrm{~min}$, redissolved in $40 \mathrm{ml}$ acetate buffer and dialysed overnight against 5 litres of the same buffer. The dialysed solution was heated at $60^{\circ} \mathrm{C}$ for $20 \mathrm{~min}$ and then transferred to an ice bath. Coagulated protein was spun down $(3000 \mathrm{~g})$ and the clear supernatant was lyophilized, dissolved in $5.0 \mathrm{ml}$ acetate buffer and applied onto a Fractogel $65(\mathrm{~S})$ column $(40 \times 3 \mathrm{~cm})$ equilibrated and eluted with the same buffer. Fractions with trehalase activity were pooled and applied to a DEAE-Trisacryl (M) column $(15 \times$ $1 \mathrm{~cm}$ ) equilibrated with $50 \mathrm{mM}$ sodium acetate buffer, $\mathrm{pH} 5 \cdot 5$, and eluted with a linear gradient of the same buffer $(50-500 \mathrm{mM})$ (Fig. 1). Fractions containing trehalase activity were pooled, dialysed against distilled water and lyophilized. After the DEAE-Trisacryl step, the enzyme preparation appeared homogeneous.
Enzyme assay. Cytosolic trehalase was routinely assayed in $50 \mathrm{mM}$ sodium acetate buffer, $\mathrm{pH} 5 \cdot 0$, as described by Zimmermann et al. (1990) and the glucose released was measured as reducing sugar (Miller, 1959). When kinetic parameters, substrate specificity or inhibition by other carbohydrates were investigated, glucose was determined by the glucose oxidase assay (Bergmeyer \& Bernt, 1974). Kinetic parameters $\left(K_{\mathrm{m}}\right.$ and $I_{\max }$ ) were analysed as described by Zimmermann et al. (1990). One unit of trehalase activity was defined as the amount of enzyme that catalyses the hydrolysis of $1 \mu \mathrm{mol}$ of trehalose $\min ^{-1}$, at $60^{\circ} \mathrm{C}$ and $\mathrm{pH} 5 \cdot 5$.

Electrophoresis. PAGE was carried out at $\mathrm{pH} 8.9$ in $6 \%(\mathrm{w} / \mathrm{v})$ acrylamide gels, according to Davis (1964). SDS-PAGE was performed by the method of Laemmli (1970) using 6\% acrylamide. Gels were stained with Coomassie blue. Molecular mass standards were: myosin $(205 \mathrm{kDa}) ; \quad \beta$-galactosidase $(116 \mathrm{kDa})$; phosphorylase $\mathrm{B}(97 \cdot 4 \mathrm{kDa})$; bovine serum albumin $(66 \mathrm{kDa})$; ovalbumin $(45 \mathrm{kDa})$ and carbonic anhydrase $(29 \mathrm{kDa})$.

Activity staining was performed by the method of Gabriel \& Wang (1969), except that glucose oxidase (30 U per gel) was fixed in the gels. Isoelectric focusing using Pharmalyte pH 2.5-5.0 was carried out in rod gels according to O'Farrell $e t$ al. (1977). The $6 \%$ gels contained $5 \%(\mathrm{v} / \mathrm{v})$ carrier ampholyte. Twenty five micrograms of purified trehalase were loaded on the gel $(0.6 \times 13.0 \mathrm{~cm})$. After focusing at $500 \mathrm{~V}$ for $6 \mathrm{~h}$, the $\mathrm{pH}$ gradient was measured by cutting one gel into $5 \mathrm{~mm}$-thick slices and extracting each slide with $1.0 \mathrm{ml} 25 \mathrm{mM} \mathrm{KCl}$. Trehalase activity staining was performed as described by Gabriel \& Wang (1969).

Fractogel column chromatography. The molecular mass of the purified cytosolic trehalase was estimated by Fractogel $55(\mathrm{~F})$ gel filtration. A sample of trehalase $(0.8 \mathrm{ml})$ was loaded onto a Fractogel column $(47.0 \times 1.8 \mathrm{~cm})$ equilibrated with $50 \mathrm{mM}$ Tris/ $\mathrm{HCl}$ buffer, $\mathrm{pH} 7 \cdot 5$, containing $100 \mathrm{mM} \mathrm{NaCl}$ and $1 \mathrm{mM}$ EDTA. Molecular mass markers were: thyroglobulin $(670 \mathrm{kDa})$; urease $(480 \mathrm{kDa}) ; \beta$-amylase $(200 \mathrm{kDa})$; alcohol dehydrogenase $(150 \mathrm{kDa})$; bovine serum albumin $(66 \mathrm{kDa})$ and carbonic anhydrase $(29 \mathrm{kDa})$. The column was eluted at $5{ }^{\circ} \mathrm{C}$ at a flow rate of $12 \mathrm{ml} \mathrm{h}^{-1}$. The eluate was collected in $1.2 \mathrm{ml}$ fractions.

Determination of neutral carbohydrate and protein. Total neutral carbohydrate was estimated by the phenol-sulfuric acid method of Dubois et al. (1956) using glucose as standard, and protein was estimated by the Lowry method using bovine serum albumin as standard.

Determination of the trehalase $\mathrm{N}$-terminal amino acid. The purified trehalase was dansylated using the procedure described by Gray (1972). Dansylated protein $(250 \mu \mathrm{g})$ was hydrolysed with $6 \mathrm{M} \mathrm{HCl}$ at $110^{\circ} \mathrm{C}$ for $24 \mathrm{~h}$. After removal of $\mathrm{HCl}$, the hydrolysate was dissolved in $25 \mu \mathrm{l} 25 \%$ (v/v) aqueous pyridine. Five microlitres of the solution were spotted on a $5 \times 5 \mathrm{~cm}$ precoated polyamine sheet. Chromatography was carried out using $1.5 \%(\mathrm{v} / \mathrm{v})$ formic acid in water, in the first direction, and benzene/acetic acid $(9: 1, \mathrm{v} / \mathrm{v})$ in the second direction at $90^{\circ}$ to the first one. After chromatography the dansylated amino acids were identified under ultraviolet light. Chromatography of a mixture of dansylated amino acid standards was carried out in a similar fashion.

Reagents. Trehalose, AMP, ADP, ATP, glucose oxidase, phenazine methosulfate, nitro blue tetrazolium, molecular mass markers for protein and dansylated amino acids were purchased from Sigma. Polyamine layer sheets were from GallardSchlesinger. 
Table 1. Purification of cytosolic trehalase from $H$. grisea var. thermoidea

\begin{tabular}{|c|c|c|c|c|c|c|}
\hline Step & $\begin{array}{c}\text { Total } \\
\text { volume } \\
\text { (ml) }\end{array}$ & $\begin{array}{c}\text { Total } \\
\text { protein } \\
(\mathrm{mg})\end{array}$ & $\begin{array}{l}\text { Total } \\
\text { units* }\end{array}$ & $\begin{array}{c}\text { Specific } \\
\text { activity } \\
{[\mathbf{U}(\mathrm{mg}} \\
\left.\text { protein })^{-1}\right]\end{array}$ & $\begin{array}{l}\text { Yield } \\
(\%)\end{array}$ & $\begin{array}{c}\text { Purification } \\
\text { (-fold) }\end{array}$ \\
\hline Crude extract & 280 & 953 & 319 & 0.33 & 100 & $1 \cdot 0$ \\
\hline $\begin{array}{l}\text { Ammonium sulfate }(75 \%) \\
\text { precipitate }\end{array}$ & 35 & 316 & 158 & $0 \cdot 50$ & 49 & $1 \cdot 5$ \\
\hline Heat shock $\left(60^{\circ} \mathrm{C}\right)$ & 35 & 107 & 150 & $1 \cdot 40$ & 47 & $4 \cdot 2$ \\
\hline Fractogel & 66 & 21 & 103 & $4 \cdot 90$ & 32 & $14 \cdot 8$ \\
\hline DEAE:-Trisacryl & 25 & $0 \cdot 3$ & 32 & $106 \cdot 66$ & 10 & $323 \cdot 2$ \\
\hline
\end{tabular}

* One unit of trehalase activity is the amount of enzyme that catalyses the hydrolysis of $1 \mu \mathrm{mol}$ trehalose $\mathrm{min}^{-1}$.

\section{RESULTS}

\section{Purification and biochemical characterization of cytosolic trehalase activity}

The enzyme was extracted from 17-h-old mycelia grown in mannitol as the carbon source; under these conditions the specific activity of the cytosolic trehalase was found to be the highest. Table 1 summarizes a typical purification of the enzyme. After DEAE-Trisacryl chromatography

(a)

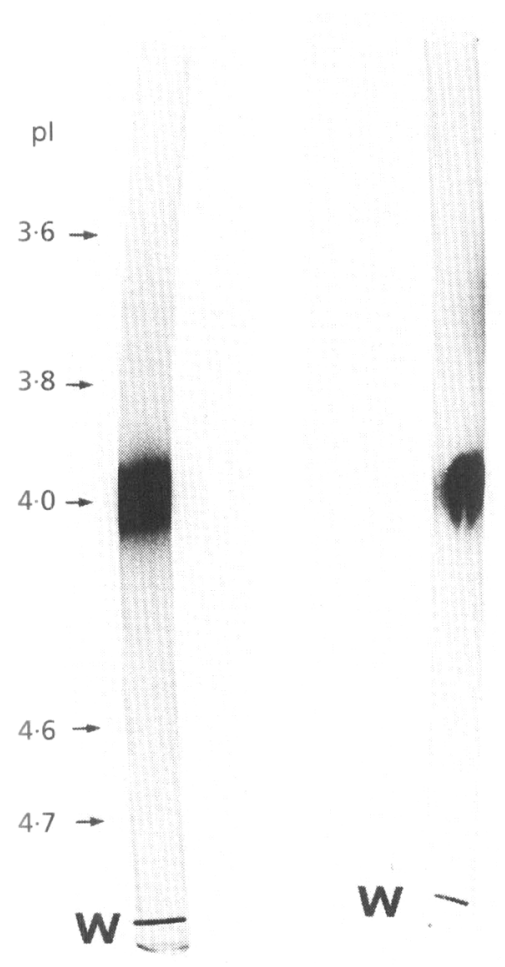

Fig. 2. Isoelectric focusing of $H$. grisea cytosolic trehalase. (a) Gel stained with Coomassie blue; (b) gel stained for activity. A piece of wire $(W)$ indicates the cathode side.
Table 2. Effect of various cations on cytosolic trehalase activity

The results are expressed as means \pm SD for at least three replicates.

\begin{tabular}{|lccc|}
\hline Salt & $\begin{array}{c}\text { Concn } \\
\text { (mM) }\end{array}$ & $\begin{array}{c}\text { Specific activity } \\
{[\mathbf{U} \text { (mg protein) }}\end{array}$ & $\begin{array}{c}\text { Activation } \\
\text { (-fold) }\end{array}$ \\
\hline Control & & $107 \pm 11$ & - \\
$\mathrm{CaCl}_{2}$ & 5 & $310 \pm 19$ & $2 \cdot 9$ \\
$\mathrm{MgCl}_{2}$ & 10 & $128 \pm 7$ & $1 \cdot 2$ \\
$\mathrm{CoCl}_{2}$ & 1 & $187 \pm 17$ & $1 \cdot 7$ \\
$\mathrm{MnCl}_{2}$ & $7 \cdot 5$ & $450 \pm 36$ & $4 \cdot 2$ \\
$\mathrm{NH}_{4} \mathrm{Cl}$ & 1 & $107 \pm 9$ & $1 \cdot 0$ \\
$\mathrm{CuSO}_{4}$ & 1 & $18 \pm 3$ & $0 \cdot 2$ \\
$\mathrm{ZnCl}_{3}$ & 1 & $102 \pm 12$ & $0 \cdot 9$ \\
$\mathrm{Al}_{2} \mathrm{Cl}_{3}$ & 1 & 0 & - \\
$\mathrm{BaCl}_{3}$ & 1 & $120 \pm 12$ & $1 \cdot 1$ \\
\hline
\end{tabular}

the specific activity of the cytosolic trehalase was about $107 \mathrm{U}$ (mg protein) $)^{-1}$ and a purification of 323 -fold was achieved. Non-denaturing- and SDS-PAGE of the purified enzyme showed a single protein band after staining with Coomassie blue. Fractogel 55 (F) gel filtration indicated that the native protein had a molecular mass of approximately $360 \mathrm{kDa}$. However, on SDS-PAGE, the purified enzyme exhibited a single band of molecular mass approximately $120 \mathrm{kDa}$, suggesting that the enzyme was formed of three subunits of molecular mass approximately $120 \mathrm{kDa}$. The N-terminal amino acid of the cytosolic trehalase was found to be glycine, and the carbohydrate content of the protein was estimated as $12 \%$ using glucose as standard. The isoelectric point of the cytosolic trehalase was $4 \cdot 0$ (Fig. 2).

\section{Catalytic properties}

The effect of several cations on the activity of the cytosolic trehalase was investigated (Table 2). Activation was observed in the presence of manganese chloride ( $4 \cdot 2$-fold), 
Table 3. Inhibition of Humicola trehalase by nucleoside phosphate

\begin{tabular}{|cccc|}
\hline $\begin{array}{c}\text { Nucleoside } \\
\text { phosphate } \\
(\mathbf{1 0} \mathbf{m M})\end{array}$ & $\begin{array}{c}\mathbf{C a C l}_{\mathbf{2}} \\
\mathbf{( \mathbf { m M } )}\end{array}$ & $\begin{array}{c}\text { Specific activity } \\
\left.[\mathbf{U} \text { (mg protein })^{-\mathbf{1}}\right]\end{array}$ & $\begin{array}{c}\text { Inhibition } \\
\mathbf{( \% )}\end{array}$ \\
\hline None & 0 & $107 \pm 9$ & \\
AMP & 0 & $102 \pm 12$ & 5 \\
ADP & 0 & $52 \pm 7$ & 51 \\
ATP & 0 & $35 \pm 5$ & 67 \\
None & 5 & $310 \pm 15$ & - \\
AMP & 5 & $282 \pm 33$ & 9 \\
ADP & 5 & $67 \pm 10$ & 78 \\
ATP & 5 & $47 \pm 8$ & 85 \\
\hline
\end{tabular}

calcium chloride (2.9-fold) and cobalt chloride (1·7-fold). Ammonium chloride had no effect and zinc chloride, magnesium chloride and barium chloride had only slight effects on the enzyme activity. Conversely, copper sulfate and aluminium chloride inhibited the enzyme activity about $83 \%$ and $100 \%$, respectively.

The effect of $\mathrm{pH}$ on the cytosolic trehalase activity was investigated using $50 \mathrm{mM}$ sodium acetate $(\mathrm{pH} 3 \cdot 0-6 \cdot 0)$ and $50 \mathrm{mM}$ Tris $/ \mathrm{HCl}(\mathrm{pH} 6 \cdot 0-9 \cdot 0)$ buffers. The enzyme showed maximal activity at $\mathrm{pH} 5 \cdot 5$. The optimum temperature for trehalose hydrolysis was $60^{\circ} \mathrm{C}$, in either the presence or the absence of $5.0 \mathrm{mM}$ calcium chloride.

In a previous study (Zimmerman et al., 1990) we demonstrated that the conidial trehalase purified from $H$. grisea is markedly inhibited by inorganic phosphate, ADP and ATP. To ascertain whether the nucleoside phosphates would similarly affect the cytosolic trehalase, the effects of AMP, ADP and ATP were tested (Table 3). At $10 \mathrm{mM}$ ADP and ATP inhibited the enzyme activity by $51 \%$ and $67 \%$, respectively. A half-maximal effect of ATP on the activity of trehalase was observed at $3.0 \mathrm{mM}$. The inhibitory effects of ADP and ATP were also
Table 5. Kinetic constants of cytosolic trehalase

\begin{tabular}{|lcc|}
\hline Treatment & $\begin{array}{c}\boldsymbol{K}_{\mathrm{m}} \\
(\mathbf{m M})\end{array}$ & $\begin{array}{c}\boldsymbol{V}_{\max } \\
{\left[\mathbf{U}(\mathbf{m g} \text { protein })^{-\mathbf{1}}\right]}\end{array}$ \\
\hline Control & $0.87 \pm 0.08$ & $392 \pm 36$ \\
$\mathrm{CaCl}_{2}(5.0 \mathrm{mM})$ & $0.89 \pm 0.04$ & $740 \pm 27$ \\
$\mathrm{MnCl}_{2}(7.5 \mathrm{mM})$ & $0.83 \pm 0.06$ & $821 \pm 65$ \\
$\mathrm{ATP}(0.5 \mathrm{mM})$ & $1.38 \pm 0.23$ & $96 \pm 14$ \\
$\mathrm{ATP}(1.0 \mathrm{mM})$ & $2.94 \pm 0.62$ & $89 \pm 19$ \\
\hline
\end{tabular}

observed in the presence of calcium where they almost entirely abolished the calcium activating effect (Table 3). In contrast, AMP only slightly inhibited trehalase activity, in either the presence or absence of calcium.

The purified cytosolic trehalase was highly specific for trehalose as a substrate and did not hydrolyse cellobiose, lactose, sucrose, maltose or raffinose. However, its activity was inhibited by cellobiose, lactose, sucrose, fructose and maltose (Table 4). This inhibition was abolished in the presence of calcium, which also stimulated trehalase activity $3 \cdot 0-3 \cdot 5$-fold (Table 4 ).

\section{Kinetic studies}

The $K_{\mathrm{m}}$ values of the cytosolic trehalase, in either the presence or absence of calcium, were essentially the same (Table 5). In contrast, calcium or manganese increased the $V_{\max } 1 \cdot 9$ - and $2 \cdot 1$-fold, respectively. The $K_{\mathrm{m}}$ values obtained in the presence of ATP suggested that the inhibitory effect of the nucleotide involved both noncompetitive and competitive mechanisms, since both $K_{\mathrm{m}}$ and $V_{\max }$ were affected.

\section{Mechanism of trehalase activation by calcium}

Aggregates of trehalase have been described previously for the enzyme purified from Neurospora crassa (Hecker \& Sussman, 1973). To ascertain whether the effect of calcium

Table 4. The effect of various carbohydrates on cytosolic trehalase activity

\begin{tabular}{|lccc|}
\hline Addition & $\begin{array}{c}\text { Activity } \\
\left(\mathbf{U ~ m l}^{-\mathbf{1}}\right)\end{array}$ & $\begin{array}{c}\text { Activation } \\
\text { (-fold) }\end{array}$ & $\begin{array}{c}\text { Inhibition } \\
\text { (\%) }\end{array}$ \\
\hline Control & $79 \pm 10$ & - & - \\
Cellobiose $(10 \mathrm{mM})$ & $36 \pm 3$ & - & 54 \\
Lactose $(10 \mathrm{mM})$ & $25 \pm 4$ & - & 68 \\
Sucrose $(10 \mathrm{mM})$ & $36 \pm 5$ & - & 54 \\
Fructose $(10 \mathrm{mM})$ & $43 \pm 7$ & - & 45 \\
$\mathrm{Maltose}(10 \mathrm{mM})$ & $36 \pm 4$ & - & 54 \\
$\mathrm{CaCl}_{2}(5 \mathrm{mM})$ & $279 \pm 14$ & $3 \cdot 5$ & - \\
$\mathrm{CaCl}_{2}(5 \mathrm{mM})+$ Fructose $(10 \mathrm{mM})$ & $279 \pm 12$ & $3 \cdot 5$ & - \\
$\mathrm{CaCl}_{2}(5 \mathrm{mM})+$ Maltose $(10 \mathrm{mM})$ & $257 \pm 10$ & $3 \cdot 2$ & - \\
$\mathrm{CaCl}_{2}(5 \mathrm{mM})+$ Cellobiose $(10 \mathrm{mM})$ & $261 \pm 18$ & $3 \cdot 3$ & - \\
$\mathrm{CaCl}_{2}(5 \mathrm{mM})+$ Lactose $(10 \mathrm{mM})$ & $249 \pm 10$ & $3 \cdot 1$ & - \\
$\mathrm{CaCl}_{2}(5 \mathrm{mM})+$ Sucrose $(10 \mathrm{mM})$ & $277 \pm 13$ & 3.5 & - \\
\hline
\end{tabular}


(a)

(b)

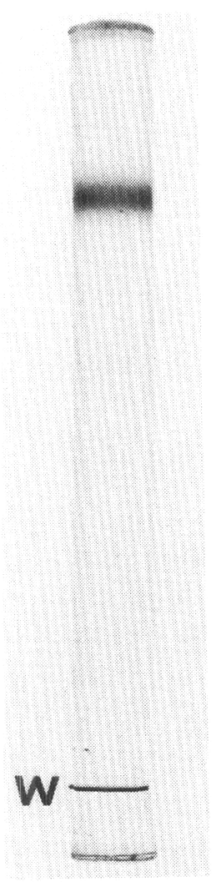

Fig. 3. Effect of calcium on the aggregation state of trehalase. After treatment with $10 \mathrm{mM}$ calcium chloride, the trehalase sample was submitted to $6 \%$ PAGE at pH 8.9. Three micrograms of trehalase per gel was applied. The gels were stained for trehalase activity. (a) Control. (b) Sample treated with calcium. Calcium was omitted in the composition of the gels and the running buffer. A piece of wire $(W)$ indicates the cathode side.

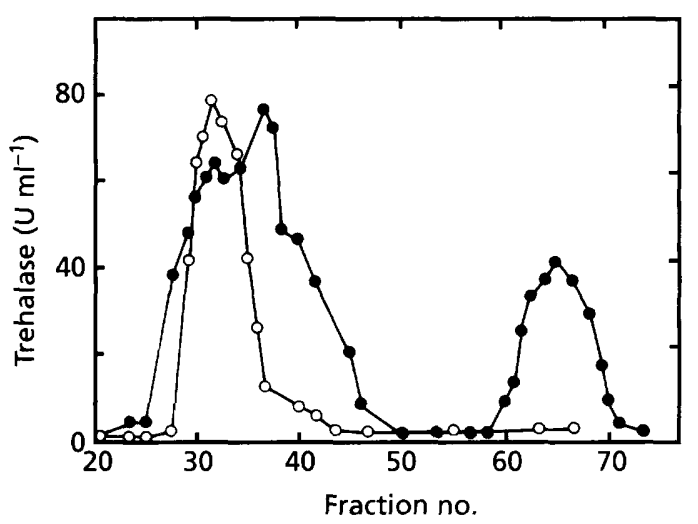

Fig. 4. Gel filtration in Sephacryl S-200 of calcium-treated purified trehalase. The column $(47.0 \times 1.5 \mathrm{~cm})$ was equilibrated and eluted with $50 \mathrm{mM}$ sodium acetate buffer $\mathrm{pH} 5 \cdot 5$, with (O) or without $(O) 100 \mathrm{mM}$ calcium chloride. Fractions $(1.2 \mathrm{ml})$ were collected at a flow rate of $12 \mathrm{ml} \mathrm{h}^{-1}$.

on trehalase activity was correlated with formation or dissociation of aggregates, the enzyme activity of calciumtreated samples was tested after electrophoresis in polyacrylamide gels. Fig. 3 shows that the sample treated with

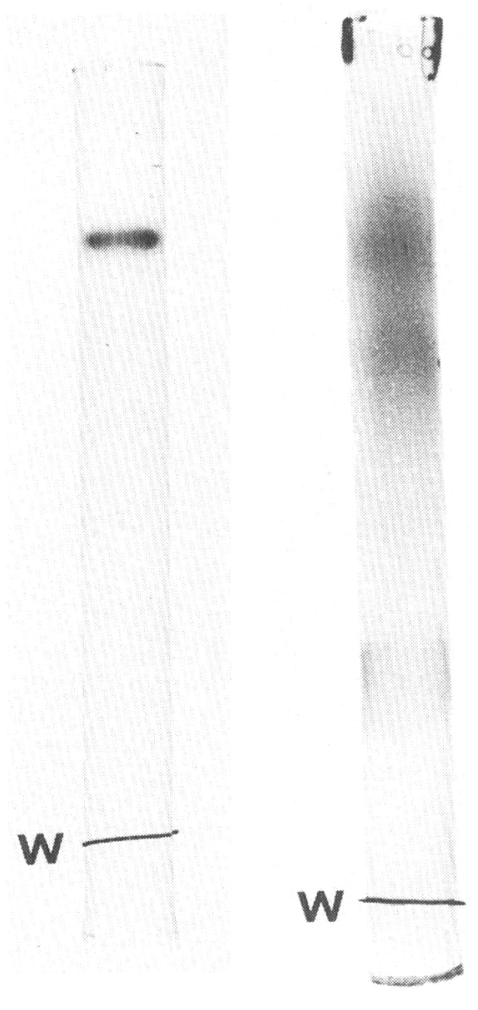

Fig. 5. Gel electrophoresis of trehalase Form III recovered from the Sephacryl S-200 column (Fig. 4). Form III was dialysed and analysed by $6 \%$ PAGE before (a) and after (b) addition of $10 \mathrm{mM}$ calcium chloride. Electrophoresis was run at $\mathrm{pH} 8.9$ and the gels were stained for trehalase activity. A piece of wire $(W)$ indicates the cathode side.

calcium dissociated into three main polypeptide components with trehalase activity, suggesting that calcium induced disaggregation of the enzyme. This was also observed by gel filtration on Sephacryl S-200 (Fig. 4). The elution profile of a trehalase sample pretreated with $10 \mathrm{mM}$ calcium chloride showed at least three peaks of activity, which were designated as Form I, Form II and Form III, following the order of outlet from the column. Form III, which might be the monomer, showed either one or three activity bands, respectively, when analysed by PAGE after dialysis or with calcium during electrophoresis (Fig. 5a, b), demonstrating that the effect of calcium was reversible.

\section{Thermoinactivation studies of the disaggregated trehalase forms}

Fig. 6 shows the thermoinactivation curves obtained at $70^{\circ} \mathrm{C}$ with the trehalase activity peaks eluted from the Sephacryl S-200 column. Forms I and II exhibited practically the same behaviour, with halflives of about 6 min. However, Form III was more labile than Forms I and II, exhibiting a halflife of about $2.5 \mathrm{~min}$. 


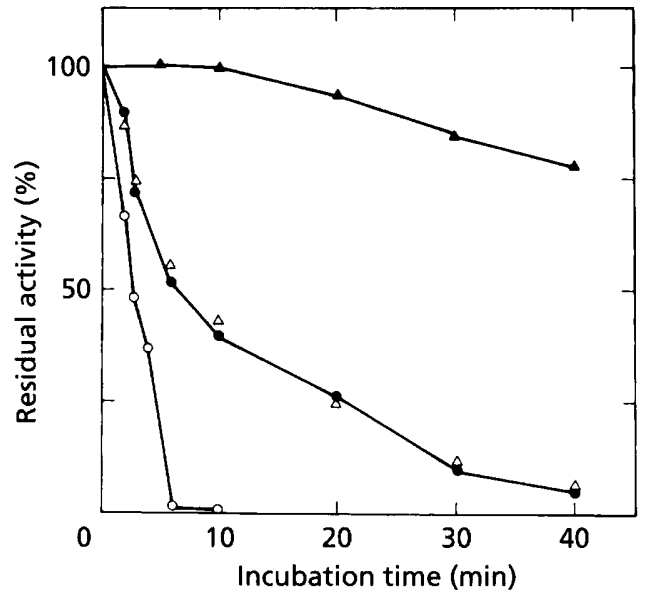

Fig. 6. Thermal denaturation at $70^{\circ} \mathrm{C}$ of the disaggregated trehalase forms. Aqueous solutions of the trehalase forms were heated in a water bath at $70^{\circ} \mathrm{C}$. Samples were withdrawn at the indicated times, chilled and tested for residual trehalase activity. O. Form I; $\triangle$, Form II; O. Form III; ( $\Delta$ ) native enzyme not treated with calcium.

\section{DISCUSSION}

The thermophilic fungus H. grisea var. thermoidea produced two trehalases with high specificity for the substrate. One of these enzymes occurs at the outer proteinaceous layer of conidia, and it has been characterized previously (Zimmerman $e$ al., 1990). In the present study we described the properties of the second $H$. grisea trehalase, a cytosolic enzyme with a specific activity of $0.33 \mathrm{U}(\mathrm{mg} \text { protein })^{-1}$ in the crude extract, much lower than that of the conidial trehalase $\left[9 \cdot 1 \mathrm{U}(\mathrm{mg} \text { protein })^{-1}\right]$. Both $H$. grisea trehalases possess remarkable thermal stability, a property which facilitates their purification (see Methods).

The purified cytosolic trehalase exhibited an apparent molecular mass of about $360 \mathrm{kDa}$ by gel filtration, but in SDS-PAGE the enzyme migrated as a single polypeptide with an approximate molecular mass of $120 \mathrm{kDa}$, suggesting that the native enzyme was formed of three seemingly identical subunits. Another example of an oligomeric trehalase is the Neurospora crassa enzyme (Hecker \& Sussman, 1973). Further evidence to support the assumption that it consists of identical subunits was that glycine was the only N-terminal amino acid found, and that a single band was found after electrofocusing and staining of the gels either for activity or protein (Fig. 2). It should be mentioned that the $\mathrm{N}$-terminal amino acid of the conidial enzyme was also found to be glycine (data not shown).

The molecular structures of the cytosolic and conidial trehalases apparently differ. The latter exhibits an apparent molecular mass of $580 \mathrm{kDa}$ and separates on SDS-PAGE into three polypeptides of 105,98 and $84 \mathrm{kDa}$, which suggest an hexameric structure (Zimmerman $e t$ al., 1990). A further structural difference between the two $\mathrm{H}$. grisea trehalases is in carbohydrate content: $12 \%$ for the cytosolic enzyme and $56 \%$ for the conidial form (Zimmerman et al., 1990).

Despite the differences in structure, the two trahalases had similar optima for temperature $\left(60^{\circ} \mathrm{C}\right)$ and $\mathrm{pH}(5.5$ and 5.6 for the cytosolic and the conidial trehalases, respectively). Both enzymes were inhibited by inorganic phosphate, ADP and ATP and were activated by manganese, calcium and cobalt, the cytosolic trehalase being more active in the presence of manganese rather than calcium (Table 2). In contrast, the two H. grisea trehalases exhibited different sensitivity to several metal ions, for example copper and aluminium ions strongly inhibited the cytosolic enzyme (Table 2 ) but were without effect on the one from conidia (Zimmerman et al., 1990). The cytosolic trehalase activity was inhibited by some carbohydrates (Table 4), which had no effect on the activity of the conidial enzyme (Zimmerman et al., 1990). The $K_{\mathrm{m}}$ values of the two $H$. grisea trehalases also differed. That for the cytosolic trehalase $(0.86 \mathrm{mM})$ was much lower than that of the conidial enzyme $(2.5 \mathrm{mM}$; Zimmerman $e t$ al., 1990).

Treatment with calcium induced disaggregation of the cytosolic trehalase, as clearly demonstrated by the separation of calcium-treated enzyme samples in SDS-PAGE (Fig. 3), or by molecular sieve chromatography (Fig. 4). Under the two conditions the calcium-treated enzyme dissociated into at least three components. The effect of calcium was fully reversible by dialysis (Fig. 5). A likely possibility was that the binding of calcium relaxed the interactions among protein monomers, thus shifting the equilibrium of the molecules toward the dissociated forms. Another important effect of calcium was to increase trehalase $V_{\max }$ about twofold (Table 5). Nevertheless, the $K_{\mathrm{m}}$ and $V_{\max }$ values of the three peaks separated by gel filtration (Fig. 4), assayed in the presence of calcium (not shown), were practically the same and very close to that of the native purified enzyme assayed in the presence of calcium (Table 5). This result suggested that disaggregation of the enzyme oligomers might not be a prerequisite for calcium-mediated activation.

The thermostability of the calcium-treated trehalase forms separated by gel filtration, indicated that the disaggregated protein was more labile to temperature than the native enzyme (Fig. 6). There are other examples in the literature of the influence of the aggregation state on the stability of enzyme molecules (Metzenberg, 1964; McFeters et al., 1969; Saddoff, 1970). With the H. grisea trehalase this property might be of physiological relevance, as this fungus is well adapted to high temperature environments.

The extracellular and the cytosolic trehalases of $\mathrm{H}$. grisea had the same N-terminal amino acid, and as the former is larger and has a higher carbohydrate content than the intracellular enzyme, we would suggest that both may share the same polypeptides, but that trehalase secretion and additional glycosylation of the protein result in different aggregated enzyme forms. Thus, the differences noted in $K_{\mathrm{m}}$, inhibition by metal ions and sugars could be explained by the different degrees of glycosylation and molecular organization of the two enzymes. In this 
respect, Buttner et al. (1991), studying the external and internal $\beta$-glucosidases and glucoamylase from the yeast Arxula adeninivorans, suggested that glycosylation combined with dimerization may be responsible for the physical and chemical differences observed between the intracellular and extracellular forms of the enzymes.

The biological role of the cytosolic trehalase of $H$. grisea is not immediately obvious. A likely possibility is that the intracellular enzyme is a storage precursor of the extracellular one. Considering their acid $\mathrm{pH}$ optima and their elevated thermoresistance, the $H$. grisea trehalases should be grouped among the so-called non-regulatory trehalases (Thevelein, 1984). Nevertheless, both enzymes exhibited some in vitro properties (e.g. sensitivity to ions, sugars, ADP and ATP) which could represent potentially regulatory parameters for modulation of their activity in vivo. Further studies may clarify this interesting question.

To conclude, and taking into account our previous studies on $H$. grisea var. thermoidea enzymes (Zimmerman et al., 1990; Peralta et al., 1990; Monti et al., 1991), we consider that this organism is a good source of potentially useful enzymes and represents a convenient model to investigate protein export and glycosylation mechanisms in filamentous fungi.

\section{ACKNOWLEDGEMENTS}

This work was supported by grants from Financiadora de Estudos e Projetos (FINEP), Fundação de Amparo à Pesquisa do Estado de São Paulo (FAPESP) and Conselho de Desenvolvimento Científico e Tecnológico (CNPq). H.F.T. and J. A. J. are Research Fellows of CNPq. L.C. was a recipient of a CAPES-PICD Fellowship. This work is part of a Doctoral Thesis submitted by L.C. to the Department of Biochemistry of the School of Medicine of Ribeirão Preto (University of São Paulo). We thank Carlos de Carvalho Almada and Maurício de Oliveira for technical assistance.

\section{REFERENCES}

App, H. \& Holzer, H. (1989). Purification and characterization of neutral trehalase from yeast ABS1 mutant. I Biol Chem 264, 17583-17588.

Bergmeyer, H. U. \& Bernt, E. (1974). In Methods of Envymatic Analysis, vol. 3, pp. 1205-1215. Edited by H. U. Bergmeyer. New York: Verlag-Chimie/Academic Press.

Büttner, R., Bode, R. \& Birnbaum, D. (1991). Comparative study of external and internal $\beta$-glucosidases and glucoamylase of Arxula adeninivorans. J Basic Microbiol 31, 423-428.

Davis, B. J. (1964). Disc electrophoresis. Ann NY Acad Sci 121, 404-427.

De Virgilio, C., Müller, J., Boller, T. \& Wiemkem, A. (1991). A constitutice, heat shock-activated neutral trehalase occurs in Schizosacchuromyces pombe in addition to the sporulation-specific acid trehalase. FHMS Microbiol Lett 84, 85-90.

Dubois, M., Gilles, K. A., Hamilton, J. K., Rebers, P. A. \& Smith, F. (1956). Colorimetric method for determination of sugars and related substances. Anal Chem 28, 350-356.
Elbein, A. D. (1974). The metabolism of $\alpha, \alpha$-trehalose. $A d v$ Carbobydr Chem Biochem 30, 227-256.

Gabriel, O. \& Wang, S.-F. (1969). Determination of enzymatic activities in polyacrylamide gels. I. Enzymes catalyzing the conversion of nonreducing substrates to reducing products. Anal Biocbem 27, 545-554.

Gray, W. R. (1972). End-group analysis using dansyl chloride. Methods Enzymol 25, 121-138.

Hecker, L. I. \& Sussman, A. S. (1973). Activity and heat stability of trehalase from the mycelium and ascospores of Neurospora. $J$ Bacteriol 115, 582-591.

Hey-Ferguson, A., Mitchell, M. \& Elbein, A. D. (1973). Trehalose metabolism in germinating spores of Streptomyces bygroscopicus. $J$ Bacteriol 116, 1084-1085.

Hirokasu, I. \& Shimoda, C. (1981). Changes in trehalose content and trehalase activity during spore germination in fission yeast, Schizosaccharomyces pombe. Arch Microbiol 129, 19-20.

Laemmli, U. K. (1970). Cleavage of structural proteins during the assembly of the head of bacteriophage T4. Nature 227, 680-685.

McFeters, G. A., Sandine, W. E., Becker, R. R. \& Elliken, P. R. (1969). Some factors affecting association-dissociation of $\beta$-galactosidase from Streptococcus lactis 792. Can J Microbiol 15, 105110.

Metzenberg, R. L. (1964). Enzymically active subunits of Neurospora invertase. Biochim Biophys Acta 89, 291-302.

Miller, G. H. (1959). Use of dinitrosalicilic acid reagent for determination of reducing sugar. Anal Chem 31, 426-429.

Mittenbühler, K. \& Holzer, H. (1988). Purification and characterization of acid trehalase from suc-2 mutant. $J$ Biol Chem 263, 8537-8543.

Monti, R., Terenzi, H. F. \& Jorge, J. A. (1991). Purification and properties of an extracellular xylanase from the thermophylic fungus Humicola grisea var. thermoidea. Can J Microbiol 37, 675-681.

O'Farrell, P. Z., Goodman, H. M. \& O'Farrell, P. H. (1977). High resolution two-dimensional electrophoresis of basic as well as acidic proteins. Cell 12, 1133-1142.

Panek, A. (1963). Function of trehalose in baker's yeast (Saccharomyces cerevisiae). Arch Biochem Biopbys 100, 422-425.

Panek, A. D. \& Souza, N. O. (1964). Purification and properties of baker's yeast trehalase. J Biol Cbem 239, 1671-1673.

Peralta, R. M., Terenzi, H. F. \& Jorge, J. A. (1990). $\beta$-D-Glycosidase activities of Humicola grisea: biochemical and kinetic characterization of a multifunctional enzyme. Biochim Biopbys Acta 1033, 243-249.

Prasad, A. R. S. \& Maheswari, R. (1978). Purification and properties of trehalase from the thermophilic fungus Humicola lanuginosa. Biochim Biophys Acta 525, 162-170.

Sadoff, H. L. (1970). Heat resistance of spore enzymes. $J$ Appl Bacteriol 33, 130-140.

Thevelein, J. M. (1984). Regulation of trehalose mobilization in fungi. Microbiol Rev 48, 4259.

Van Laere, A. (1989). Trehalose, reserve and/or stress metabolite? FEMS Microbiol Rev' 63, 201-210.

Zimmerman, A. L. S., Terenzi, H. F. \& Jorge, J. A. (1990). Purification and properties of an extracellular conidial trehalase from Humicola grisea var. thermoidea. Biochim Biophys. Acta 1036, 41- 46.

Received 16 September 1993; revised 18 January 1994; accepted 22 February 1994. 